\title{
Ler Nietzsche como "nietzschiano": Questões de método
}

\section{Scarlett Marton \\ Universidade de São Paulo}

\section{RESUMO}

Tomando como ponto de partida a análise das passagens em que Nietzsche fornece a seus leitores as indicaçōes de como desejaria ser lido, este artigo conta, num primeiro momento, mostrar a sua insuficiência. Propondo-se discutir questôes metodológicas, pretende evidenciar a especificidade do texto nietzschiano e as formas de abordá-lo.

\section{PALAVRAS-CHAVE}

Nietzsche; Metodologia; Leitura; Comentário.

\begin{abstract}
Taking as point of departure the analysis of the texts where Nietzsche provides his readers with the indications of how they should read his works, this paper aims first of all at pointing its insufficiency. Trying to discuss methodological issues, it intends to highlight the specificity of Nietzsche's writings as well as its approach.
\end{abstract}

\section{KEY WORDS}

Nietzsche; Methodology; Reading; Commentary. 
Ao levantar questões de ordem metodológica no trato com os textos do autor de Zaratustra, o estudioso em geral se pergunta de que modo ler Nietzsche como nietzschiano, de que maneira compreendê-lo tal como ele mesmo se compreendeu. $\mathrm{E}$ a resposta que lhe vem ao espírito quase sempre é esta: seguindo as indicações que fornece a seus leitores. Embora essas indicações estejam presentes em vários momentos de sua obra, são poucos os textos em que o filósofo procura explicitálas. Examiná-los constituirá o ponto de partida de nossa investigação.

I.

No final do prólogo a Aurora, redigido em 1886, Nietzsche menciona o fato de tê-lo incluído no livro poucos anos após sua publicação em I88I, quando da primeira edição. Depois de fazer o elogio da falta de pressa, referindo-se tanto ao que essa obra apresenta quanto ao seu próprio procedimento, ele afirma: "não se foi filólogo em vão, talvez se seja ainda, isto é, um mestre da lenta leitura”. E, logo adiante, acrescenta: "[a filologia] ensina a ler bem, ou seja, lentamente, com profundidade, olhando para trás e para diante, com segundas intençôes, deixando as portas abertas, com dedos e olhos delicados... Meus pacientes amigos, este livro deseja apenas leitores e filólogos perfeitos: aprendei a ler-me bem!"' Aqui, Nietzsche caracteriza a filologia como a arte de ler bem e expressa o desejo de encontrar leitores que se portem como filólogos. Por um lado, cumpre salientar que, ao empregar na última linha da passagem citada o verbo "aprender" no imperativo e, ainda grifado, ele revela a intenção de estabelecer uma relação singular com seus leitores; seus escritos deles parecem reclamar um aprendizado preciso: o de se converterem em filólogos. Por outro, é preciso ressaltar que, ao sublinhar o advérbio "bem", quando trata da filologia, deixa entrever que é preciso distinguir entre as diversas maneiras de ler. Num conhecido parágrafo de Para além de Bem e Mal, ele virá a diferenciar as artes de interpretação, dando a entender haver as boas e as ruins ${ }^{2}$; de igual modo, no prólogo a Aurora, posicionase em relação aos procedimentos de leitura.

Da sua perspectiva, "ler bem" significa adotar em face do texto uma atitude que implica necessariamente evitar a precipitação. Ao recomendar que se leia lentamente, Nietzsche estaria alinhado com o momento inaugural da

I Aurora, "Prefácio", $\$$ 5, KSA 3.I7. Salvo indicação em contrário, é de nossa responsabilidade a tradução das passagens dos textos de Nietzsche aqui citadas.

2 Cf. Para além de Bem e Mal \$22, KSA 5.37. Tradução conforme Rubens Rodrigues Torres Filho (Nietzsche, 1972). A partir de agora indicado como RRTF. Nessa passagem, lemos: "perdoem este velho filólogo, que não pode resistir à maldade de pôr o dedo sobre artes-de-interpretação ruins: mas aquela 'legalidade da natureza', de que vós físicos falais com tanto orgulho, como se... — só subsiste graças a vossa interpretação e 'filologia' ruim”. 
modernidade, que tem em Descartes sua figura emblemática. Como sabemos, nas primeiras linhas do Discurso do Método, o pensador francês faz o elogio da lentidão, ao prenunciar as origens do erro. Tanto é que afirma: "As maiores almas são capazes dos maiores vícios, tanto quanto das maiores virtudes, e os que só andam muito lentamente podem avançar muito mais se seguirem sempre o caminho reto, do que aqueles que correm e dele se distanciam".

Mas, à diferença de Descartes, Nietzsche não está preocupado em elencar preceitos, que, se bem seguidos, conduzirão à descoberta da "verdade nas ciências". Nada mais distante de seu horizonte de reflexão. Vale lembrar que ele não cessa de criticar a vontade de verdade que domina a atividade filosófica dos seus pares. A esse respeito, que se acrescente ainda outro ponto: ao tratar do método, o autor de Zaratustra não visa aos resultados de seu trabalho, mas tem em mente sobretudo os seus leitores. Bem mais do que qualquer outro filósofo, parece empenhado em fornecer-lhes indicações sobre como quer ser lido. No prólogo a Aurora, deixa claro que a prática da leitura de seus textos, além da lentidão, tem de contar com o aprofundamento que dela decorre. Tem de contar ainda com a precaução, uma vez que demanda que se leia "olhando para trás e para diante", e com a sutileza, já que exige que se leia "com dedos e olhos delicados".

Além do parágrafo de Aurora, a que acabamos de nos ater, impóe-se examinar o final do prólogo à Genealogia da Moral. Também nessa passagem Nietzsche se expressa sobre procedimentos de leitura. Embora não esteja se referindo explicitamente à filologia, escreve: "para praticar assim a leitura como arte, é preciso antes de tudo uma coisa que em nossos dias precisamente melhor se desaprendeu - e por isso passará tempo até que meus escritos sejam "legíveis" uma coisa para a qual é preciso ser quase uma vaca e não um "homem moderno": o ruminar..." Aqui, ele retoma um elemento do que julga constituir a boa leitura de seus textos e apresenta um aspecto dos leitores que gostaria de ter. Cada um desses pontos exige nossa atenção. Ao concluir o parágrafo com o termo "ruminar", o filósofo incentiva seus leitores a adotar um procedimento de leitura que, além de contemplar a lentidão, implica o trabalho paciente da volta reiterada ao texto; incita-os a não desprezar a sutileza. Se no prólogo a Aurora Nietzsche caracterizava a filologia como a arte de ler bem, agora, sem dela tratar, deixa claro que, frente a seus textos, se deve praticar a "leitura como arte". Mas é precisamente nisso que consiste o exercício filológico.

A maneira pela qual o filósofo entende que se deva fazer filologia aparece sobretudo em seus primeiros escritos. No Nascimento da Tragédia, fornece um

3 Descartes, 1962, p. 4I.

4 Genealogia da Moral, "Prefácio", \$8, KSA 5.256. 
exemplo; nas conferências Sobre o Futuro de nossas Instituiçôes de Formação, faz um apelo. Na Consideração Extemporânea, Nós, Filólogos, que então planeja mas não chega a escrever, pretende explicitar o que pensa a respeito. ${ }^{5}$ Nos fragmentos póstumos do período, deixa claro que o filólogo, além de pesquisador especializado, deve em certa medida ter alma de artista. A ele cabe a paciente tarefa de reconstruir os textos, recuperar os documentos, resgatar o que ficou enterrado sob os barbarismos dos copistas. Indispensável, o trabalho de erudição revela-se, porém, insuficiente. Não é por acaso que, quando da publicação do Nascimento da Tragédia, Nietzsche prefere não responder às criticas que Ulrich von Wilamowitz lhe dirige; julga inócuo entabular uma discussão erudita. ${ }^{6}$ A seu ver, o filólogo deve ter entusiasmo criador e o mais delicado sentido da forma, para fazer ressurgir a beleza dos antigos e até mesmo resgatar sua concepção de cultura. ${ }^{7}$

Filólogo de formação, Nietzsche julga que é preciso reinscrever as línguas clássicas no contexto cultural de que fazem parte, de modo a superar o ensino inconsequente e mecânico que se faz delas. Acredita que, com isso, o estudo do alemão também se beneficiaria, sendo revitalizado pelo sentido de harmonia estética que a arte e a literatura gregas inspiram. Com Ritschl ${ }^{8}$, muito cedo aprendera que a filologia podia favorecer uma nova visão da cultura, que ela devia concorrer para ressuscitar a civilização integral de um povo. Por isso mesmo, de seus leitores espera que se distingam do "homem moderno": que à precipitação oponham a lentidão, que à pressa desenfreada contraponham a paciência. Ciente de que essa maneira de proceder não está na ordem do dia, incita-os a ruminarem seus textos. Lançando um olhar crítico sobre o presente, julga que demorará tempo até que suas obras se tornem "legíveis".

Depois de tratar de procedimentos de leitura nos prólogos de 1886 a Aurora e à Genealogia da Moral, o filósofo volta ao tema numa passagem de Ecce Homo: "que, nos meus escritos, fala um psicólogo sem igual, é talvez a primeira constatação a que chega um bom leitor - um leitor tal como mereço e que me lê como os

5 A expressão "Wir Philologen" aparece como título no Fragmento póstumo 2 do início de março de I875, KSA 8.II, e no Fragmento póstumo 3 de março de I875, KSA 8.I4; o plano do que viria constituir mais uma Consideração Extemporânea se encontra no Fragmento póstumo 2 [3] do mesmo período, KSA 8.II.

6 A esse propósito, cf. Dixsaut, 1995.

7 São muitas as anotações póstumas em que Nietzsche trata da tarefa que lhe parece competir ao filólogo. Cf. por exemplo Fragmento póstumo 3 [4], 3 [2I] e 3 [62] de março de I875, KSA 8.I4S, KSA 8.2I e KSA 8.3I; 5 [39] da primavera/verão de I875, KSA 8.5I; 7 [7] do verão de I875, KSA 8.I25ss.

8 Como sabemos, Nietzsche segue os cursos do eminente helenista em Bonn durante o ano letivo de I864-I865; continua os estudos de filologia clássica em Leipzig, acompanhando o mestre que para lá se mudara. A propósito da influência que Ritschl exerceu sobre Nietzsche, cf. Andler, 1958, vol. 2, pp. 294-309. 
bons filólogos de outrora liam Horácio". ' Aqui, ele expressa uma vez mais o desejo de ter leitores que se portem como filólogos. Mas, a partir de outra abordagem, em vez de a eles fazer recomendaçóes, procura mostrar os resultados a que chega quem pratica a arte de ler bem; esse é capaz de apreender a perspectiva que ele adota em seus escritos, ou seja, que neles "fala um psicólogo sem igual".

Se em Humano, demasiado Humano Nietzsche concebe de início a psicologia como o estudo da proveniência e história dos sentimentos morais, a partir de Assim falava Zaratustra, ao introduzir na sua obra a noção de valor, passa a identificá-la ao procedimento genealógico. Ao psicólogo tocaria questionar o valor dos valores morais, examinando as condições e circunstâncias de seu nascimento, de seu desenvolvimento, de sua modificação. A ele caberia relacionar os valores com as avaliaçôes de que procedem e investigar de que valor estas partiram para criá-los. Numa palavra, ao psicólogo competiria a tarefa de avaliar as avaliações. ${ }^{\text {Io }}$

Ora, é precisamente à critica dos valores que o filósofo dedica a maior parte de seus escritos. Não é por acaso, pois, que, nos textos de maturidade, insiste em autodenominar-se psicólogo. ${ }^{\text {II }}$ É nessa condição que ele ataca tudo o que é fruto de idealizações; examina os tipos decadentes que, em geral, são tomados pelos mais sábios entre os homens; revela a condição de que partem os filósofos e os procedimentos a que recorrem para procederem à desvalorização do mundo em que nos achamos aqui e agora; diagnostica os diferentes tipos de degenerescência. Em suma: faz da civilização ocidental uma crítica radical.

É ainda dessa perspectiva que Nietzsche critica as transformaçôes por que passa o trabalho filológico. No início do século XIX, por ocasião da fundação da Universidade de Berlim levada a bom termo por Wilhelm von Humboldt em I8Io ${ }^{\mathrm{I2}}$, a filologia constitui-se como "ciência da Antiguidade" [Altertumswissenschaft]. Gozando de um estatuto privilegiado no contexto universitário, ela permite que se ensine aos jovens as línguas clássicas e ao mesmo tempo a eles se proponha um modelo estético e moral inspirado na antiga Grécia. O filólogo desempenha então um duplo papel: o de modelo de "cientificidade" e o de promotor de um programa

9 Ecce Homo, "Por que escrevo livros tão bons", \$ 5, KSA 6.305.

IO Sobre a concepção e o estatuto da psicologia na obra nietzschiana, remetemos a Marton, 20IO, em particular o segundo capítulo. Cf. também Marton, 20I4b, em particular pp. 322-330.

II Cf. Ecce Homo, "Por que escrevo livros tão bons", $\$$ 5, KSA 6.305. Cf. ainda Para além de Bem e Mal \$ 23, KSA 5.39; Genealogia da Moral, "Terceira Dissertação", \$ I9 e $\$ 20$, KSA 5.387; Ecce Homo, "Por que sou um destino", \$5, KsA 6.369. Convém lembrar que o escrito Nietzsche contra Wagner traz o subtítulo "Dossiê de um psicólogo" e Crepúsculo dos Ídolos foi primeiramente intitulado "Divagações de um psicólogo".

I2 Cf. a propósito da relação entre Humboldt, a Universidade de Berlim e o ideário neo-humanista Spranger, I9IO. 
pedagógico ${ }^{13}$ Mas, a partir de I830, tal ideário deixa de ser levado em conta pela Prússia; mostra-se infrutífera a tentativa de concretizá-lo ao nível das instituições de formação. Por volta de I870, ao constatar o fracasso do empreendimento, Nietzsche virá a lamentar o que ocorreu. Do ponto de vista "científico", a filologia sofre uma involução deixando-se impregnar pelo espírito positivista. Com a proliferação de ramos anexos, transforma-se num vasto empreendimento de edições e comentários de textos, assim como de pesquisa de fontes. Do ponto de vista pedagógico, ela deixa de promover o modelo estético e moral inspirado na antiga Grécia. Com a unificação alemã em torno da Prússia e a consequente fundação do II Reich, tal modelo se revela inadequado ao espírito da época.

Enquanto psicólogo, Nietzsche se posiciona contra o seu tempo por um tempo por vir. É o que o leva a instar junto a seus leitores para que pratiquem, frente a seus textos, a arte de ler bem. Portando-se como filólogos, eles poderiam perceber a partir de onde ele fala; bem mais, poderiam compreender o diagnóstico que faz do mundo em que vive e, quiçá, contribuir para transformá-lo.

As análises precedentes permitem notar dois resultados. O primeiro diz respeito ao desejo que o filósofo expressa de encontrar leitores que se portem como filólogos e o segundo, às indicações que fornece sobre como quer ser lido. Quanto ao primeiro ponto, estamos em condiçôes de afirmar que, mais do que apontar as veleidades de um autor quanto à recepção de seus escritos, seu desejo revela a maneira pela qual concebe o empreendimento filosófico. Encontrar leitores que se portem como filólogos é parte integrante de seu projeto enquanto "médico da civilização". Quanto ao segundo ponto, constatamos que as três passagens, que acabamos de examinar, têm em comum a ideia de que é na prática da filologia que reside a arte da boa leitura.

Para aprofundar nossa investigação acerca da questão principal que nos ocupa, a saber, de que modo ler Nietzsche como nietzschiano, vale trazer neste momento um parágrafo do Anticristo em que o filósofo esclarece precisamente o que entende por filologia. Criticando o modo de proceder dos sacerdotes e dos teólogos, que, dado sua "falsidade instintiva", sentem "o prazer de mentir por mentir", ele aponta como um de seus traços distintivos a "incapacidade para a filologia". E, então, define: "por filologia, deve-se entender, num sentido bem geral, a arte de ler bem, - poder decifrar fatos sem falseá-los com interpretaçóes, sem perder, na exigência de compreensão, a precaução, a paciência, a sutileza" ${ }^{\text {I4 }}$

I3 Cf. Thouard, 200o, p. 156.

I4 O Anticristo $\$ 52$, KSA 6.233. Cf. ainda Fragmento Póstumo I9[I] de outubro/dezembro de I876, KSA 8.332. A propósito da concepção de filologia presente em $O$ Anticristo, remetemos a Marton, 20I4a, em particular o capítulo intitulado "O Anticristo. Cristianismo: da má filologia à corrupção dos instintos”. 
Aqui, por assim dizer, ele resume as características da boa leitura. Trata-se de pôr-se diante do texto de tal modo que, ao lê-lo, se evite a precipitação, por um lado, e se cultive a precaução e a sutileza, por outro.

Essas indicações de procedimentos de leitura são as que se tende a tomar como a primeira máxima metodológica a ser seguida por todo aquele que procura abordar de forma criteriosa os textos nietzschianos. Enquanto filólogo, Nietzsche incentivaria seus leitores a observá-las no trato com seus próprios textos; enquanto “professor da lenta leitura”, ele poderia encorajá-los a pô-las em prática de maneira bem mais ampla.

\section{II.}

É bem verdade que as indicações fornecidas pelo autor de Zaratustra sobre como desejaria ser lido poderiam nos pôr de sobreaviso quanto a alguns riscos a que eventualmente se acharia exposto o estudioso de seu pensamento. Nos nossos dias, um deles decorreria de uma aproximação eminentemente técnica de seus escritos. Ao deter-se no exame de problemas bem delimitados, tende-se a operar recortes no corpus nietzschiano e privilegiar textos isolados. É certo que, hoje, os estudos pontuais encontram lugar no contexto da pesquisa internacional acerca das ideias nietzschianas; também é certo que as análises de conjunto ainda são imprescindíveis. São elas que permitem ultrapassar abordagens que se apresentam como parcelares e, por conseguinte, sempre parciais.

Ora, ao recomendar a precaução, o filósofo demanda que se leia seus escritos “olhando para trás e para diante". Dessa recomendação, não seria desmedido inferir a necessidade de contextualizá-los. E tal necessidade se faz sentir de diversas maneiras. No caso de estudos pontuais, julgamos necessário contextualizar os problemas a serem examinados, recorrendo a uma visão de conjunto da obra de Nietzsche. Esse modo de proceder, assim nos parece, permite perceber nos seus textos bem mais do que a associação livre de ideias ou a justaposição de meras opiniōes. Concorre ainda para que se apreenda o sentido e se aquilate o valor de seu empreendimento filosófico.

Ao dedicar-se a um trabalho desse teor, o estudioso terá necessariamente de defrontar-se com algumas questôes, tais como a da unidade ou descontinuidade da obra de Nietzsche. No nosso entender, é de modo progressivo que ele explicita a maneira pela qual concebe seu empreendimento filosófico. ${ }^{15}$ Mas se o fato não acarreta momentos de ruptura em seu pensamento, nem por isso deixa de revelar mudanças de atitude dignas de nota. Uma coisa é afirmar que sua filosofia consiste na explicitação progressiva das ideias; outra é sustentar que tais ideias ou parte

I5 Quanto a este ponto, alinhamo-nos à posição de Kaufmann, I950. 
delas não sofrem alterações. Mas também uma coisa é, seguindo o hábito, já contestado, reconhecer três períodos em sua obra, dividi-la em compartimentos estanques, unidades fechadas em si mesmas; outra é estabelecer parâmetros para localizar o aparecimento de conceitos centrais e detectar as transformações por que eles passam.

Contextualizar os conceitos a serem trabalhados, considerando sua inscrição nos textos do filósofo, também se nos afigura indispensável. Para tanto, cumpre recuperar as etapas do processo de elaboração de suas ideias e apontar as diversas apropriações que Nietzsche faz em diferentes momentos de seu itinerário. Mas não caberia ater-se aos dados biográficos do autor, que não bastam para esclarecer a obra, nem aos temas de que trata, presentes por vezes em todos os textos. São os referenciais teóricos por ele adotados, durante os vinte anos em que permaneceu intelectualmente ativo, que se teria de levar em conta.

Contextualizar a obra nietzschiana no quadro da história da filosofia é, a nosso ver, imprescindível. Não hesitaríamos em afirmar que não se pode comentá-la sem recorrer a um quadro histórico. Pois, muitos dos equívocos que ocorreram e ainda ocorrem no trato com a obra de Nietzsche se devem ao fato de não se levar em conta seus interlocutores. Para dirimir esse problema, grande foi a contribuição dada pela publicação do catálogo da sua biblioteca pessoal, que trouxe a descrição, página por página, dos rastros que as leituras que realizou deixaram em seus livros conservados nos Arquivos Nietzsche em Weimar. ${ }^{16}$ Pesquisas que levem em conta esse material poderiam concorrer para identificar fontes de que se serviu e de que, de modo sempre original, se apropriou. ${ }^{17}$

Investigar com quem o filósofo está a dialogar implica necessariamente reinscrevê-lo em sua época, recuperar o confronto com contemporâneos e predecessores, resgatar referenciais teóricos, filosóficos e científicos. Para tanto, é preciso o esforço sempre renovado de situar o pensamento nietzschiano não apenas no quadro da história da filosofia, mas também no contexto da história cultural e factual da Europa. Pois, é só fazendo de Nietzsche um pensador do século XIx que se poderá realçar o caráter radical e inovador de sua reflexão.

Outro risco a que eventualmente se acharia exposto o estudioso de seu pensamento reside em abordagens tendenciosas, que buscam resolver problemas que emergem de seus textos, desprezando a lógica que lhes é própria. Exemplo desse procedimento, encontramos na tentativa de cristianizar as ideias presentes

I6 Cf. Campioni, D’Iorio, Fornari, Fronterotta, Orsucci, Müller-Buck (Orgs.), 2003.

I7 Segundo Montinari, tal tarefa consistiria no "complemento necessário do trabalho desenvolvido com a edição, não só para uma compreensão mais clara dos textos, mas também para recolocá-los numa frutífera conexão com a realidade histórica" (Campioni, Venturelli (Orgs.), 1992, "Introduzione”, pp. 8-9). 
nos seus escritos. Procedendo dessa maneira, acaba-se por propor uma leitura redutora da filosofia nietzschiana, aprisionando-a na malha de referenciais teóricos que lhe são estranhos. Daí, a importância dos estudos de recepção do pensamento de Nietzsche. São eles que permitem descartar abordagens de seus escritos, que permanecem atreladas a crenças e convicções alheias à sua maneira de pensar.

Ora, ao recomendar a sutileza, o filósofo exige do leitor que leia seus escritos "com dedos e olhos delicados"; encoraja-o a observar a riqueza da pontuação, atentar para a plurivocidade dos termos, ler nas entrelinhas. Mas, é preciso frisar, o objetivo que persegue consiste em ser bem compreendido. Em diversos textos, ele expressa essa preocupação; nos livros Assim falava Zaratustra e Ecce Homo, é com clareza que a ilustra.

No início da segunda parte de Assim falava Zaratustra, o protagonista acorda, certa manhã, sobressaltado com um sonho. Depois de relatá-lo, procura interpretálo. Então, diz ao seu coração: "bem demais compreendo o sentido e o aviso do sonho: meu ensinamento corre perigo, o joio quer chamar-se trigo! Meus amigos tornaram-se poderosos e desfiguraram a imagem do meu ensinamento, de tal sorte que aqueles que mais amo devem envergonhar-se das dádivas que lhes dei”. ${ }^{18}$

No prólogo a Ecce Homo, o autor começa por anunciar que, dado seu intuito de trazer à humanidade o projeto de transvaloração de todos os valores, dado seu propósito de em breve lançar em várias línguas $O$ Anticristo, julga indispensável apresentar-se. Embora não se cansasse de escrever e publicar, embora não se deixasse "sem testemunho", reconhece a necessidade de cumprir o que lhe cabe, ou seja, dar-se a conhecer, a fim de fazer-se compreender. É nesse contexto que declara: "Nessas circunstâncias há um dever, contra o qual se revolta, no fundo, meu hábito, e mais ainda o orgulho de meus instintos, ou seja, de dizer: Ouçam! pois eu sou tal e tal. Não me confundam, sobretudo!’”9

Estamos, pois, em condições de afirmar que, já na sua época, o filósofo se preocupa com a recepção de suas ideias. No nosso entender, a história da recepção de seu pensamento permite combater preconceitos, crenças e convicções que a ele vieram associar-se no correr das décadas; ela torna possível desmontar as mais variadas imagens que se colaram à figura do filósofo ao longo de mais de um século. É bem verdade que um trabalho dessa ordem implica o entrecruzamento de várias linhas de pesquisa: da história factual, passando pela cultural, até a institucional; da história das mentalidades, passando pelas transferências sócioculturais, até o exame da constituição das redes de poder.

Pronto a separar o joio do trigo, o estudioso poderá, enfim, travar um diálogo e duelo com a obra de Nietzsche. Ciente de que dela existem leituras plausíveis e

I8 Assim falava Zaratustra II, "O menino com o espelho", KSA 4.IO5s.

I9 Ecce Homo, "Prólogo", \$ I, KSA 6.257, tradução de RRTF. 
outras inapropriadas, ele se perguntará por certo pelo critério para distingui-las. E, então, terá de se haver com estas questôes: estaria sua leitura contaminada pelo dogmatismo que impera em tantas outras? Seria também ela ditada por uma insidiosa vontade de verdade?

III.

Contudo, quando se trata das indicaçôes que Nietzsche dá a seus leitores sobre como quer ser lido, é preciso, sem dúvida, levantar algumas questôes. A primeira que exige nossa atenção diz respeito ao propósito por ele perseguido ao fornecer tais indicações. Retomemos as passagens examinadas.

Em Ecce Homo, quando dá a entender que espera que o leiam como "os bons filólogos de outrora liam Horácio", cabe perguntar se o filósofo está efetivamente se limitando a expressar o desejo de encontrar um "bom leitor". Pois, nessa mesma passagem, ele acrescenta: "um leitor tal como mereço". Entende que ler os seus textos como faria um filólogo é requisito necessário para tornar-se um bom leitor. Mas não se limita a fazer aqui uma exigência; deixa ainda entrever que o leitor, que vier a cumpri-la, fará jus à sua obra.

No prólogo a Aurora, antes de incitar seus leitores a procederem como filólogos e, enquanto tais, a aprenderem a ler seu livro, ao apresentá-lo, Nietzsche escreve no mesmo parágrafo: "por que deveríamos dizer tão alto e com tal prontidão o que somos, o que queremos ou não queremos? Olhemos isso de modo mais frio, mais distante, mais judicioso, de mais alto; com mais prudência, de uma maior altura; digamos isso, como pode ser dito entre nós, tão discretamente que todo mundo não o ouça, que todo mundo não nos ouça!" ${ }^{\prime 20}$ Nessa passagem, em que o pronome oblíquo "nos" aparece grifado, o filósofo parece querer tomar seus leitores por cúmplices. Mas essa cumplicidade, ele procura estabelecê-la apenas com aqueles que julga serem os leitores que merece.

Por fim, no prólogo à Genealogia da Moral, antes de encorajar seus leitores a se dedicarem à prática de ruminar os textos e, dessa forma, contribuírem para tornar sua obra "legível", Nietzsche escreve nesse mesmo parágrafo: "se este livro for incompreensível para alguém, ou dissonante aos seus ouvidos, a culpa, ao que me parece, não será necessariamente minha” ${ }^{21}$ Com essa passagem, ele expressa, de maneira contundente, seu intuito: não quer qualificar todos os seus leitores, incitando-os a se portarem como filólogos. Tanto é que supõe possível, e mesmo provável, que existam aqueles que jamais tenham condiçôes de compreender sua obra.

20 Aurora, "Prefácio", \$ 5, KSA 3.I7.

2I Genealogia da Moral, "Prefácio", $\$ 8$, KSA 5.255. 
Os elementos reunidos até agora permitem-nos afirmar que, ao fornecer indicações sobre como quer ser lido, Nietzsche está a escolher os seus leitores. Seguindo o impulso de dirigir-se aos mais seletos, aos que têm ouvidos finos, aos que lhe são aparentados, ele apresenta-lhes exigências que, sem dúvida, denotam um caráter seletivo.

Nesse momento de nossa investigação, poderíamos examinar um de seus primeiros escritos com vistas a fortalecer nossa hipótese. Já no prefácio às conferências Sobre o Futuro de nossas Instituiçōes de Formação, Nietzsche fornece a seus leitores as indicaçōes sobre como quer ser lido. Então, afirma: "o leitor de quem espero algo deve ter três qualidades: deve ser calmo e ler sem pressa, não deve sempre intervir com a sua pessoa e a sua 'cultura' e não deve, enfim, esperar algo próximo a programas como resultado no final". ${ }^{22}$ Aqui, ele reitera uma vez mais suas prescrições. Impõe-se, antes de mais nada, ler sem pressa, pôr-se à escuta do texto, procurar manter-se fiel a ele. Cabe, também, proceder de modo a evitar que opiniões, achismos, preferências inclusive, venham a se interpor entre o texto e o leitor. É preciso, por fim, empenhar-se em não aprisionar o texto numa camisa de força, que acabe por convertê-lo na apresentação de verdades últimas e definitivas e reduzi-lo a uma exposição doutrinária. Em suma, frente aos seus textos, trata-se, por um lado, de evitar a precipitação e, por outro, de cultivar a precaução e a sutileza.

Cumpre notar, porém, que, ao lado das indicações que fornece a seus leitores sobre como deseja ser lido, Nietzsche já expressa nesse escrito suas convicções acerca daqueles que o lerão. Tanto é que assegura: "este livro é destinado aos leitores calmos, às pessoas que ainda não estão comprometidas com a pressa vertiginosa de nossa época de correria e ainda não experimentam um prazer idólatra em ser esmagadas por suas rodas, ou seja, a poucas pessoas!" ${ }^{23}$

Para o autor de Zaratustra, é recorrente a necessidade de eleger seus interlocutores. Perseguindo a ideia segundo a qual "para aquilo a que não se tem acesso por vivência, não se tem ouvido" ${ }^{24}$, ele aspira a quem comungue suas experiências, deseja quem o apreenda e compreenda. No decorrer de sua obra, persevera em dirigir-se a um leitor refinado, em voltar-se para quem tiver ouvidos finos. ${ }^{25}$ Enquanto a plebe se denuncia por suas orelhas compridas ${ }^{26}$, ele

22 Sobre o futuro de nossas Instituiçôes de Formação, "Prefácio", KSA I.648.

23 Sobre o futuro de nossas Instituiçôes de Formação, "Prefácio", KSA I.649.

24 Ecce Homo, "Por que escrevo livros tão bons", \$ I, KSA 6.300.

25 Cf. Assim falava Zaratustra I, "Das moscas do mercado", KsA 4.66; Assim falava Zaratustra I, "Da virtude que dá", \$2, KSA 4.IOO; Assim falava Zaratustra IV, "A canção bêbada", $\$ 4$, KSA 4.399 .

26 Cf. Assim falava Zaratustra I, "Do novo ídolo", KsA 4.62; Assim falava Zaratustra IV, 
evidencia a necessidade de ir ao encontro de quem dela se diferencia. "Tens orelhas pequenas", dirá Dioniso a Ariadne, "tens os meus ouvidos" ${ }^{27}$ Em seus escritos, Nietzsche reitera sem cessar a necessidade de interlocutores específicos.

Prova disso é que, ao lado das indicações que ele fornece a seus leitores, proliferam as afirmaçôes em que declara que não é a todos que dará a chave de entrada a seus textos. Na Gaia Ciência, é taxativo: "Não se quer apenas ser compreendido, quando se escreve, mas também, por certo, não ser compreendido. Não é de modo algum uma objeção contra um livro, se quem quer que seja o acha incompreensível; talvez isto mesmo fizesse parte das intençōes do escritor, - ele não queria ser compreendido por 'quem quer que seja'. Todo espírito, todo gosto mais elevado, escolhe para si os seus ouvintes, quando quer comunicar-se; ao escolhê-los, impõe limites a 'os outros'. Aí têm origem todas as leis mais sutis de um estilo: elas afastam, criam distância, proíbem 'a entrada', a compreensão, como se diz, - enquanto abrem os ouvidos dos que são de ouvidos aparentados aos nossos" ${ }^{28} \mathrm{Em}$ muitos aspectos, essa passagem é reveladora da atitude de Nietzsche em relação a seus leitores. Ela bem mostra que, ao escolher um estilo, burilá-lo, aprimorá-lo, o autor seleciona o seu leitor. Repele quem lhe é estranho; atrai quem é do seu feitio. Tudo se passa como se o estilo fosse um mot de passe, uma mensagem cifrada, uma senha. Apresentando-a, o autor lança sua isca ${ }^{29}$; decifrando-a, o leitor dele se mostra digno. É desse modo que o filósofo seleciona seus interlocutores. No limite, seria possível afirmar que, à diferença do que se passa com seus pares, não são os leitores que escolhem ler os textos de Nietzsche; é ele quem elege por quem quer ser lido e, há que se acrescentar, compreendido.

\section{IV.}

A segunda questão que caberia levantar acerca das indicações fornecidas por Nietzsche a seus leitores diz respeito ao estatuto que elas possuem. Não é, sem dúvida, enquanto um receituário que se deve tomá-las. Em outras palavras: os textos nietzschianos não comportam um manual que ensinaria ao leitor a maneira pela qual ele deveria lê-los. Pensar de outro modo implicaria resvalar no dogmatismo, adotando uma atitude que estaria longe de ser do gosto do filósofo.

"Colóquio com os reis", \$I, KSA 4.306; Assim falava Zaratustra IV, "Do homem superior", S I e $\$ 5$, KSA 4.356 e KSA 4.359 .

27 Ditirambos de Dioniso, "Lamento de Ariadne", KSA 6.40I.

28 A gaia Ciência $\$ 38$ I, KSA 3.633-634.

29 Cf. Assim falava Zaratustra Iv, "O sacrifício do mel”, ksA 4.297, em que Zaratustra declara: "Com a minha melhor isca, fisgo hoje para mim os mais raros peixes humanos!" Cf. também Ecce Homo, "Para além de Bem e Mal", \$ I, KSA 6.350, em que Nietzsche afirma que, a partir de Para além de Bem e Mal, "todos os meus escritos são anzóis: quem sabe eu entenda de pesca tanto quanto ninguém?... Se nada mordeu, não foi culpa minha. Faltavam os peixes..." 
A situação se agrava quando o estudioso se dá conta de que o próprio Nietzsche exige que não se aplique a seus textos as mesmas abordagens que comumente se aplica a seus pares. Pois, a Nietzsche não escapam os elementos distintivos de sua reflexão, elementos esses que o distanciam de seus pares. À diferença de seus pares, não organiza com cuidado um plano de trabalho, permanecendo fiel a ele até a sua mais completa realização. Não toma as próprias reflexões como partes necessárias de uma totalidade previamente dotada de coerência. Tanto é que não se aplica a refutar os sistemas de seus predecessores; tampouco se empenha em aplaudir a verdade que julgam anunciar. Bem ao contrário, o autor de Zaratustra conta revelar as artimanhas das posiçōes que seus pares defendem e fazer ver a astúcia que lhes é própria. Trata de apreender os parti pris velados de um procedimento lógico, captar os pré-juízos subjacentes a uma argumentação, diagnosticar o nãodito de um autor. Em suma, ao trazer à luz o ardil dos filósofos, quer denunciar em que medida eles se acham comprometidos com uma certa concepção do homem e do mundo, até que ponto são cúmplices do processo de decadência da nossa civilização.

Por isso mesmo, a Nietzsche não se pode aplicar as mesmas técnicas de análise que comumente se aplica a outros autores; a ele não se pode fazer exigências análogas às que se faz a seus pares; em suma: não se pode lê-lo como se lê a maioria dos filósofos. ${ }^{30}$ Uma vez que critica a vontade de verdade, não caberia apreciar até que ponto suas considerações são verdadeiras ou falsas. Já que ataca a lógica dualista presente no pensar metafísico e na fabulação cristã, não seria o caso de reclamar um raciocínio linear, que distinguiria com clareza o sim e o não. $\mathrm{Na}$ medida em que combate os sistemas filosóficos, não se deveria exigir de seus textos longas cadeias argumentativas e minuciosas demonstraçôes. Em suma, Nietzsche não se limita a acenar com outra maneira de conceber a atividade filosófica; ao contrário, está determinado a pô-la em prática. ${ }^{31}$

Há quem sustente que se deva recorrer a um único e mesmo método ao abordar todo e qualquer texto filosófico. No caso da obra de Nietzsche, porém, tal posição é dificilmente defensável. É bem verdade que a análise estrutural é de fundamental importância para a compreensão do texto filosófico. E, quando se tem diante dos olhos o texto nietzschiano, que apresenta procedimentos tão singulares, ela se revela uma ferramenta de valor inestimável. Mas essa abordagem constitui apenas uma primeira etapa do trabalho exegético. É certo que se trata de uma etapa necessária; também é certo que ela terá de ser completada pela abordagem genética. Refazer a trama dos conceitos presentes na obra de Nietzsche

30 A esse propósito, remetemos à análise esclarecedora de Wotling, 20I3, pp. 3I-5I.

3I Para uma análise mais aprofundada desse ponto, remetemos a Marton, 2009, pp. I67-I84. 
e reconstituir seu percurso intelectual apresentam-se como etapas complementares; mais ainda, constituem trabalhos imprescindíveis.

Mas, no trato com os escritos do filósofo, outras abordagens são igualmente bem-vindas. Bem sabemos que é indispensável a quem se dispõe a ler os seus textos ater-se aos diversos procedimentos de que ele lança mão. Para dar-se conta de sua reflexão, o leitor tem de frequentar sua obra, explorar suas tramas conceituais, atentar para a pluralidade de seus estilos, conviver com suas estratégias. Esses dois últimos pontos merecem nossa atenção. Pois, dada a diversidade estilística e a riqueza estratégica que apresenta, o corpus nietzschiano presta-se a aproximaçōes distintas e variadas.

Fino estrategista, com frequência, Nietzsche não hesita, num primeiro momento, em converter em aliados seus adversários; dando a entender que assume as posições que advogam, evidencia os pontos vulneráveis daqueles que, então, se dispõe a questionar; contesta, por fim, estes que, de início, tomara por cúmplices. Dependendo dos alvos de ataque que elege e dos interlocutores que escolhe, a uma mesma proposição confere um tom assertivo ou irônico, dubitativo ou jocoso. É preciso, pois, explorar não apenas o que ele diz mas sobretudo como ele diz, a quem se endereça e contra quem se dirige.

Dentre os procedimentos singulares de que Nietzsche lança mão, há que se notar, também, suas escolhas estilísticas. Não seria desmedido afirmar que, na sua obra, não há lugar para a separação entre forma e conteúdo. Que se tome, por exemplo, Assim falava Zaratustra. Nele, o autor agencia um conteúdo filosófico e uma forma literária, que se mostram indissociáveis. À primeira vista, a nova linguagem que inventa parece uma mistura de "verdade" e "poesia" - o que contribuiria para reforçar a posição de que ele não passa de literato ou poeta. Desta perspectiva, o livro poderia ser lido como um "romance de aventuras", uma vez que conta as peripécias de Zaratustra, ou um "romance psicológico", já que enfatiza sua vida interior, ou até mesmo, a exemplo do Werther de Goethe e da Educação sentimental de Flaubert, como um "romance de formação". Mas, importa salientar que, recusando-se a opor ciência e sabedoria, Nietzsche tenta então recuperar a unidade original do conceito e da imagem. E, com isso, retorna ao gênero do poema didático, a que recorreram pensadores de Parmênides a Lucrécio. ${ }^{33}$

32 Cf. Pautrat, 1971, em particular p. 336.

33 Alinhamo-nos aqui às posições de Löwith, 1978, que entende ser Nietzsche o renovador moderno da língua mais antiga da filosofia. 
Contudo, em sua correspondência, Nietzsche também deixa entrever que seu Zaratustra poderia pertencer a outra rubrica, "quase à das 'sinfonias"”34, ou ser "uma espécie original de pregação moral", "uma poesia ou um quinto 'Evangelho"”, "um livro sagrado". ${ }^{35}$ Ao referir-se à obra de maneiras tão distintas, talvez enfatize justamente o que mais a caracteriza. Ao apresentá-la como sinfonia, pregação moral, poesia ou livro sagrado, faz ver que ela se oferece de todas essas maneiras sem identificar-se com nenhuma delas em particular. ${ }^{36}$ Numa carta a seu editor, ele sugere que seu livro bem poderia ser "algo para o qual ainda não existe nome". ${ }^{37}$ Esta passagem mostra que bem sabe das múltiplas implicações da forma estilística que adota; bem mais, ela revela que tem ciência dos múltiplos recursos de que lança mão para encontrar a linguagem adequada para o que tem a dizer. ${ }^{38}$

V.

E, aqui, voltamos à questão inicial que nos propusemos investigar: de que modo ler Nietzsche como nietzschiano. Para tanto, já vimos, não basta seguir as indicações dadas pelo filósofo a seus leitores. De caráter geral, elas poderiam ser aplicadas a qualquer texto filosófico; no limite, a qualquer texto. No trato com os escritos nietzschianos, não há um único método a ser seguido. Vários são os expedientes a que o estudioso terá de recorrer: a análise estrutural e a abordagem genética dos textos, a visão de conjunto da obra, sua contextualização tanto no quadro da história da filosofia quanto no da história cultural e factual europeia, a pesquisa das fontes de que o filósofo se serviu e se apropriou, os estudos de recepção de suas ideias, a investigação acerca das estratégias que elegeu, o exame dos múltiplos estilos de que lançou mão. E, como ponto de partida de seu trabalho, terá de proceder à escolha criteriosa do material, privilegiando edições qualificadas e, quando necessário, traduções confiáveis do corpus nietzschiano, além de sempre partir do status questionis para não arrombar portas abertas.

34 Cf. carta a Heinrich Köselitz de 2 de abril de I883, кsв 6.353.

35 Cf. respectivamente carta a Heinrich Köselitz de I ${ }^{\circ}$ de fevereiro de I883, KSB 6.32I; carta a Ernst Schmeitzner de I3 de fevereiro de I883, KsB 6.327; carta a Malwida von Meysenbug de 20 de abril de I883, КSв 6.363 .

36 Seguimos aqui o comentário de Salaquarda, I997, que afirma: "todas essas caracterizações põem em evidência um aspecto importante (do livro), mas somente um aspecto. [...] Mas cada um dos aspectos citados também não é correto, na medida em que a rubrica se altera, quando nela se inclui a obra" (p. I8).

37 Cf. carta a Ernst Schmeitzner de I3 de fevereiro de I883, кsв 6.327.

38 Na carta a Franz Overbeck de 5 de agosto de I886, KsB 7.223, Nietzsche escreve: "É um livro incompreensivel, porque remete a vivências contundentes que não partilho com ninguém. Se pudesse lhe dar uma ideia de meu sentimento de solidão! Nem entre os vivos nem entre os mortos tenho alguém de quem me sinta aparentado". 
Essas práticas, que encontram ilustração nos artigos deste número da revista Discurso, nós as adotamos no GEN - Grupo de Estudos Nietzsche desde a sua fundação. Foi no final da década de 1980 que, imbuída do espírito que ainda animava o Departamento de Filosofia da usp, concebi e implementei o grupo de pesquisa. Com a sua implementação, persegui o propósito primeiro de contribuir para formar estudantes que, por sua vez, se tornariam formadores. Aprendera que a ideia de formação se achava ligada à história e à memória. À memória de uma maneira de refletir sobre textos filosóficos e a partir daí levar adiante a investigação. À história de uma instituição, de uma cidade, de um país. Não se tratava de limitar-se a transmitir experiências passadas, mas de através delas construir algo novo, necessário. Assim é que, ao ler os clássicos, o estudante se punha em contato com um referencial, que o auxiliava a organizar sua experiência interior e a fazer dela algo coletivo em vista de um futuro.

Hoje, o GeN - Grupo de Estudos Nietzsche é um grupo de pesquisa internacional, que reúne estudiosos brasileiros e europeus da filosofia nietzschiana. ${ }^{39}$ Presente em todo o Brasil, do Ceará ao Rio Grande do Sul, ele continua a perseguir o propósito de fazer avançar as investigaçóes acerca do pensamento nietzschiano. Empreendimento pioneiro na América do Sul, o GEN - Grupo de Estudos Nietzsche procura não apenas incentivar os estudos nietzschianos no Brasil como dialogar com as diversas Nietzsche Societies e Centros de Pesquisa internacionais (www.gen-grupodeestudosnietzsche.net). Empenhando-se em consolidar parcerias intelectuais e acadêmicas, participa de congressos e publicações internacionais voltados para os estudos nietzschianos. Assim é que seus membros integram o GIRN - Groupe International de Recherches sur Nietzsche e o Hyper Nietzsche, apresentando trabalhos nos congressos e publicações por eles organizados.

É em permanente diálogo com diferentes linhas interpretativas do pensamento nietzschiano que o GEN - Grupo de Estudos Nietzsche segue o seu trabalho. Não há dúvida de que a diversidade constitui nossa maior riqueza. Se assim me empenhei na criação, fortalecimento e consolidação do nosso grupo de pesquisa, não foi para criar uma escola. Mas, quem sabe, levar adiante uma história.

\section{Referências}

ANDler, C. Nietzsche, sa vie et sa pensée. Paris: Gallimard, 1958. 3 vols.

Campioni, G., D’Iorio, P., Fornari, M. C., Fronterotta, F., Orsucci, A., Müller-Buck, R. (Orgs.). Nietzsches persönliche Bibliothek. Berlim: Walter de Gruyter, 2003.

39 Para uma exposição mais detalhada das atividades do GEN - Grupo de Estudos Nietzsche, remetemos a Marton, 20I6. Cf. também Marton, 2012. 
Campioni, G., Venturelli, A. (Orgs.). La "biblioteca ideale" di Nietzsche. Nápoles: Guida Editori, 1992.

Descartes. Discurso do Método, in Obra escolhida. Trad. Jacob Guinsburg e Bento Prado Júnior. São Paulo: DIFEL, 1962.

Dixsaut, M. (Org.). Querelle autour de "La naissance de la tragédie". Paris: J. Vrin, I995.

Löwiтн, K. Nietzsches Philosophie der ewigen Wiederkehr des Gleichen. $3^{\text {a }}$ edição. Hamburgo: Felix Meiner Verlag, 1978.

Kaufmann, W. Nietzsche, Philosopher, Psychologist, Antichrist. Princeton: Princeton University Press, I950.

Marton, S. "Afternoon Thoughts. Nietzsche and the Dogmatism of Philosophical Writing”. In: Cosntâncio, J.; Branco, M. (Orgs.). Nietzsche on Instinct and Language. Berlim: Walter de Gruyter, 2009, pp. I67-I84.

Marton, S. Nietzsche, das forças cósmicas aos valores humanos. $3^{\text {a }}$ edição. Belo Horizonte: Editora da UFMG, 2010.

Marton, S. "Gen - uma experiência de formação". In: Cadernos Nietzsche 30 (maio de 2012), pp. 303-319.

Marton, S. Nietzsche e a arte de decifrar enigmas. Treze conferências europeias. São Paulo: Edições Loyola, 20I4a (Coleção Sendas \& Veredas).

Marton, S. "À la recherche d'un critère d'évaluation des évaluations. Les notions de vie et de valeur chez Nietzsche”. In: Denat, C.; Wotling, P. (Orgs.). Les hétérodoxies de Nietzsche. Lectures du Crépuscule des idoles. Reims: Épure, 20I4b, pp. 32I-342.

Marton, S. "International Nietzsche Research Group in Brazil: GEN - Nietzsche Studies Group". In: The Journal of Nietzsche Studies $47 \mathrm{n}^{\circ} 3$ (Autumn 2016), pp. 479-487.

Nietzsche. Sämtliche Werke. Kritische Studienausgabe (KSA), organizadas por Giorgio Colli e Mazzino Montinari. Berlim: Walter de Gruyter \& Co, 1967/1978. I5 vols.

Nietzsche. Sämtliche Briefe. Kritische Studienausgabe (кsв), organizadas por Giorgio Colli e Mazzino Montinari. Berlim: Walter de Gruyter \& Co, 1986. 6 vols.

Nietzsche. Obras incompletas. Trad. Rubens Rodrigues Torres Filho. $2^{\mathrm{a}}$ edição. São Paulo: Abril Cultural, 1972 (Coleção Os Pensadores).

Pautrat, B. Versions du Soleil. Paris: Seuil, I97I.

Salaquarda, J. "A concepção básica de Zaratustra". Trad. Scarlett Marton. In: Cadernos Nietzsche 2 (maio de 1997), pp. 17-39. 
Spranger, E. Wilhelm von Humboldt und die Reform des Bildungswesen. Berlim: Reuther, I9IO.

Thouard, D. "Le centaure et le cyclope. Nietzsche et la philologie entre critique et mythe”. In: Crépon, Marc. Nietzsche. Paris: Éditions de l'Herne, 2000.

Wotling, P. Nietzsche e o problema da civilização. Trad. Vinicius de Andrade. São Paulo: Editora Barcarolla, 2013 (Coleção Sendas \& Veredas). 